\title{
Erratum to: Ethical Leadership, Organic Organizational Cultures and Corporate Social Responsibility: An Empirical Study in Social Enterprises
}

Palvi Pasricha ${ }^{1}$ (D) Bindu Singh ${ }^{1} \cdot$ Pratibha Verma $^{1}$

Published online: 27 June 2017

(C) Springer Science+Business Media B.V. 2017

Erratum to: J Bus Ethics

DOI 10.1007/s10551-017-3568-5

The original version of this article was corrected: hypotheses numbers and accompanying text were updated.

The online version of the original article can be found under doi:10.1007/s10551-017-3568-5.

Palvi Pasricha

durgaddm@iitr.ac.in; palvipasrichaiitr@gmail.com

Bindu Singh

bindu.iitr15@gmail.com

Pratibha Verma

pratibha.iitr2015@gmail.com

1 Department of Management Studies, Indian Institute of Technology (IIT), Roorkee 247667, India 